\title{
Urgensi dan Efektifitas Sanksi Administrasi dalam Pengelolaan Limbah Bahan Berbahaya dan Beracun
}

\author{
Siti Ruhama Mardhatillah \\ Fakultas Hukum Universitas Islam Indonesia Yogyakarta \\ Jln. Tamansiswa No. 158 Yogyakarta \\ titilaw10@gmail.com
}

\begin{abstract}
The implementation of administrative sanctions in Government Regulation No. 101 of 2014 on the Management of Hazardous and Toxic Waste (B3) has emerged a polemic in the form of inconsistency in the sanction enforcement under Act No. 32 of 2009 on the Protection and Management of the Environment (Law $P P L H)$. Under the provisions concerning with the management of $B 3$ waste as regulated in the Act of PPLH, criminal sanction is enforced as premium-remedium without any first enforcement of administrative sanctions. This study observed two issues: first, the urgency and the strategy of sharpening the existence of the administrative sanctions in the Regulation No. 101 of 2014 of the Law No. 32 of 2009. Second, it concerns with the effectiveness of the administrative sanctions in the management and supervision of $B 3$ waste. This is a normative juridical law research. The study concluded that: first, although based on the law of PPLH criminal law is enforced in medium premium, but the role and presence of the administrative sanctions in the $B 3$ waste management is necessary especially to develop any preventive measures against environmental pollution caused by the B3 waste. Second, although the Act of PPLH has applied the criminal sanctions in premium remedium, but the implementation of administrative sanctions is more effective and provides a protection against the threat of environmental pollution from waste B3.
\end{abstract}

Keywords: Urgency, effectiveness, administrative sanction, Hazardous and Toxic Waste (B3).

\begin{abstract}
Abstrak
Pemberlakuan sanksi administrasi dalam Peraturan Pemerintah Nomor 101 Tahun 2014 tentang Pengelolaan Limbah Bahan Berbahaya dan Beracun (limbah B3) menimbulkan polemik berupa inkonsistensi penegakan sanksi berdasarkan Undang-Undang Nomor 32 Tahun 2009 tentang Perlindungan dan Pengelolaan Lingkungan Hidup (UU PPLH). Berdasarkan ketentuan mengenai pengelolaan limbah B3 yang diatur dalam UU PPLH, sanksi pidana ditegakkan secara premium remedium tanpa perlu ditegakkannya sanksi administrasi terlebih dahulu. Penelitian ini mengkaji dua permasalahan: pertama, urgensi serta strategi penajaman keberadaan sanksi administrasi dalam PP Nomor 101 Tahun 2014 terhadap UU Nomor 32 Tahun 2009. Kedua, mengenai efektifitas sanksi administrasi dalam pengelolaan dan pengawasan limbah B3. Penelitian ini merupakan penelitian hukum yuridis-normatif. Hasil penelitian menyimpulkan bahwa: pertama, meskipun berdasarkan UU PPLH hukum pidana ditegakkan secara premium remedium, namun peran dan keberadaan sanksi administrasi dalam pengelolaan limbah B3 sangat dibutuhkan terutama untuk mengembangkan upaya preventif terhadap pencemaran lingkungan akibat limbah B3. Kedua, meskipun UU PPLH menerapkan sanksi pidana secara premium remedium, akan tetapi penerapan sanksi administrasi lebih efektif dan lebih memberikan perlindungan terhadap lingkungan hidup dari ancaman pencemaran limbah B3.
\end{abstract}

Kata-kata kunci: Urgensi, efektifitas, sanksi administrasi, limbah B3. 


\section{Pendahuluan}

Undang-Undang Nomor 32 Tahun 2009 tentang Perlindungan dan Pengelolaan Lingkungan Hidup (UU PPLH) merupakan bukti dari kemajuan Indonesia dalam memandang pentingnya kelestarian lingkungan hidup. Jika ditelusuri, perubahan undang-undang pokok lingkungan hidup mulai dari UU Nomor 4 Tahun 1982 yang kemudian digantikan oleh UU Nomor 23 Tahun 1997 (UU PLH) yang pada akhirnya juga digantikan oleh UU Nomor 32 Tahun 2009 (UU PPLH), terdapat beberapa perubahan yang bersifat fundamental. Salah satu perubahan yang cukup mendasar dari perubahan UU PLH menjadi UU PPLH adalah mengenai penerapan sanksi. Undang-Undang PLH lebih mengedepankan sanksi yang bersifat administratif tidak lain dikarenakan UU tersebut menekankan pada aspek pengelolaan lingkungan, sedangkan pengelolaan selalu dikaitkan dengan wewenang dan wewenang itu sendiri merupakan fokus utama dari hukum administratif. Sehingga dalam banyak kasus lingkungan, ketentuan dalam UU PLH cenderung menerapkan sanksi administrasi terlebih dahulu sedangkan sanksi pidana dijatuhkan apabila sanksi administrasi dianggap tidak efektif atau tidak menjerakan. Maka dari itu, sanksi pidana dalam UU PLH bersifat ultimum remedium yang artinya bahwa berlakunya sanksi pidana itu berdasarkan pada asas subsidiaritas, bahwa sanksi pidana baru akan didayagunakan apabila sanksi bidang hukum lain, seperti sanksi administrasi dan sanksi perdata, serta alternatif penyelesaian sengketa lingkungan hidup tidak efektif dan/atau tingkat kesalahan pelaku relatif berat dan/atau akibat perbuatannya relatif besar dan/atau perbuatannya menimbulkan keresahan masyarakat. ${ }^{1}$ Sedangkan dalam UU PPLH, penerapan sanksi lebih mengedepankan sanksi pidana sebagai premium remedium kecuali terhadap tiga bentuk pelanggaran yang ditentukan dalam Pasal 100 UU PPLH yaitu terhadap pelanggaran baku mutu air limbah, baku mutu emisi, dan baku mutu gangguan. Selain dari tiga bentuk pelanggaran tersebut UU PPLH mengatur bahwa penegakan hukum pidana serta merta diterapkan tanpa mempertimbangkan efektif tidaknya sanksi administrasi dan ganti kerugian yang juga diterapkan.

${ }^{1}$ Lidya Suryani Widyawati, “Ultimum Remedium dalam Bidang Lingkungan Hidup”, Jurnal Hukum Ius Quia Iustum, Volume 22, Nomor 1, Januari 2015, hlm. 10-11. 
Ancaman sanksi pidana yang diterapkan secara premium remedium juga berlaku dalam hal pengelolaan limbah bahan berbahaya dan beracun (limbah B3). Pengaturan limbah B3 tersebut terdapat dalam Pasal 59 ayat (1) UU PPLH yang menyebutkan bahwa "Setiap orang yang menghasilkan limbah B3 wajib melakukan pengelolaan limbah B3 yang dihasilkannya" dan Pasal 59 ayat (4) yang menyebutkan bahwa "Pengelolaan limbah B3 wajib mendapat izin dari Menteri, gubernur, atau bupati/walikota sesuai dengan kewenangannya". Pelanggaran terhadap dua ketentuan tersebut berdasarkan UU PPLH diancam dengan sanksi pidana yang diatur dalam Pasal 102 UU PPLH bahwa: "Setiap orang yang melakukan pengelolaan limbah B3 tampa izin sebagaimana dimaksud dalam Pasal 59 ayat (4), dipidana dengan pidana penjara paling singkat 1 (satu) tahun dan paling lama 3 (tiga) tahun dan denda paling sedikit Rp1.000.000.000,00 (satu miliar rupiah) dan paling banyak Rp. 3.000.000.000,00 (tiga miliar rupiah)" dan dalam Pasal 103 UU PPLH: "Setiap orang yang menghasilkan limbah B3 dan tidak melakukan pengelolaan sebagaimana dimaksud dalam Pasal 59, dipidana dengan pidana penjara paling singkat 1 (satu) tahun dan paling lama 3 (tiga) tahun dan denda paling sedikit Rp. 1.000.000.000,00 (satu miliar rupiah) dan paling banyak Rp. 3.000.000.000,00 (tiga miliar rupiah)." Berdasarkan ketentuan tersebut, penegakan hukum pidana dapat serta merta dilakukan tanpa mempertimbangkan diterapkannya sanksi administrasi terlebih dahulu. Terlebih lagi perumusan delik pidana yang diancamkan terhadap pelanggaran ketentuan Pasal 59 ayat (1) dan (4) adalah delik formal yang artinya pelaku dapat dijatuhi sanksi pidana apabila terbukti melanggar ketentuan formal Pasal 59 ayat (1) dan (4) tanpa perlu melihat dan membuktikan apakah pelanggaran tersebut menimbulkan kerugian bagi pihak lain.

Akan tetapi dikarenakan pengelolaan limbah B3 tersebut merupakan salah satu dari kewenangan pemerintah untuk mengatur dan merumuskan kebijakan, maka UU PPLH berdasarkan Pasal 59 ayat (7) menentukan bahwa "Ketentuan lebih lanjut mengenai pengelolaan limbah B3 diatur dalam Peraturan Pemerintah". Dengan demikian terdapat pendelegasian kewenangan kepada pemerintah untuk melakukan pengelolaan limbah B3 yang selanjutnya dituangkan dalam peraturan pelaksana yang lebih rendah melalui Peraturan Pemerintah Nomor 101 Tahun 2014 tentang Pengelolaan Limbah Bahan Berbahya dan Beracun (PP Nomor 101 Tahun 
2014). Dalam PP tersebut, pengelolaan limbah B3 dijabarkan secara lebih rinci yang terdiri dari: pengurangan, penyimpanan, pengumpulan, pengangkutan, pemanfaatan, pengolahan, dan/atau penimbunan. Peraturan Pemerintah Nomor 101 Tahun 2014 menentukan apabila di setiap tahapan pengelolaan tersebut tidak disertai izin, maka dapat dikenakan sanksi administrasi yang artinya terhadap satu pelanggaran ketentuan yang bersifat administratif, dikenakan dua macam sanksi, sanksi pidana dan sanksi administrasi.

Namun demikian, penjatuhan dua jenis sanksi terhadap satu bentuk pelanggaran administratif dipandang terlalu berlebihan. Selain itu, penegakan dari delik pidana formalnya pun juga tidak begitu efektif. Organ pemerintah yang membidangi masalah lingkungan hidup (Badan Lingkungan Hidup) seringkali lebih cepat mendeteksi terjadinya pelanggaran ketentuan perijinan atau ketentuan administrasi lainnya dalam pengelolaan limbah B3 dibandingkan aparat kepolisian. Di samping itu, penjatuhan sanksi administrasi yang dilakukan secara bertahap dipandang relatif lebih mudah dibandingkan penegakan hukum pidana yang harus dilakukan oleh pihak kepolisian (yang tupoksinya tidak secara khusus menangani persoalan perlindungan lingkungan) dan membutuhkan waktu yang relatif lama.

\section{Rumusan Masalah}

Dari uraian latarbelakang masalah di atas, permasalahan yang akan dibahas dalam penelitian ini adalah: pertama, apa urgensi diberlakukannya instrumen sanksi administrasi dalam pengelolaan limbah B3? Kedua, bagaimana efektivitas sanksi administrasi dalam pengelolaan limbah B3 dibandingkan dengan sanksi pidana?

\section{Tujuan Penelitian}

Penelitian ini bertujuan untuk mengetahui urgensi penajaman sanksi administrasi dan efektivitas sanksi administrasi dibandingkan sanksi pidana dalam pengawasan dan pengelolaan limbah B3 serta bertujuan mengkaji kembali konsep sanksi pidana sebagai premium remedium dalam pengawasan dan pengelolaan limbah B3.

\section{Metode Penelitian}

Penelitian ini menggunkana metode penelitian yuridis-normatif dengan metode pendekatan konseptual dan pendekatan perundang-undangan. Data yang 
digunakan adalah data sekunder yang diperoleh melalui studi pustaka. Data yang terkumpul kemudian dianalasis dan disajikan secara deskriptif analitif.

\section{Hasil Penelitian dan Pembahasan}

\section{Urgensi Sanksi Administrasi dalam Pengelolaan Limbah B3}

Kebijakan hukum lingkungan Indonesia meletakkan hukum lingkungan sebagai bagian dari lapangan hukum administrasi yang lebih menekankan peran pemerintah sebagai bestuur. Salah satu obyek pengaturan pemerintah dari bidang lingkungan hidup adalah pengelolaan limbah B3 yang merupakan sisa hasil dari penemuan-penemuan dalam bidang ilmu pengetahuan alam dan teknologi yang dimanfaatkan oleh sektor-sektor industri, pertanian, kesehatan, militer, dan energi di banyak negara, termasuk Indonesia. Akan tetapi, aktivitas tersebut dipandang sebagai sumber resiko lingkungan, karena dapat menimbulkan pencemaran lingkungan dengan akibat-akibat serius seperti kematian massal, penyakit kanker, perubahan genetika, dan lahirnya bayi-bayi dalam keadaan cacat. Keberadaan dari limbah B3 tersebut rentan menimbulkan kerugian bagi kualitas lingkungan, kesehatan dan keselamatan makhluk hidup sehingga pengelolaannya diatur di dalam UU PPLH dengan menerapkan tiga instrumen hukum yaitu hukum administrasi, hukum perdata, dan hukum pidana. Gustaf A. Biezeveld menggambarkan penegakan hukum lingkungan sebagai berikut:2

"Environmental law enforcement can be defined as the application of legal governmental powers to ensure compliance with environmental regulations by means of: $a$. administrative supervision of the compliance with environmental regulations (inspection) (=mainly preventive activity); $b$. administrative measures or sanctions in case of non compliance $=$ corrective activity); $c$. criminal investigation in case of presumed offences (= repressive activity); d. criminal measures or sanctions in case of offences (= repressive activity); e. civil action (law suit) in case of threatening non compliance (=preventive or corrective activity)".

Ketiga instrumen hukum tersebut harus diterapkan secara harmonis, tidak tumpang tindih, serta efektif dan efisien bagi perlindungan lingkungan hidup. Instrumen hukum baik administrasi, perdata, maupun pidana hanya dapat diterapkan apabila terdapat mekanisme penegakan hukum, baik secara preventif

2 Gustaf A. Biezeveld, dalam Teguh Sulistia dan Aria Zurnetti, Penegakan Hukum Lingkungan Pidana sebagai Ultimum Remedium, hlm. 108. 
maupun secara represif yang disertai dengan perangkat sanksi. Notitie Handhaving dalam Koesnadi Hardjosoemantri merumuskan penegakan hukum sebagai: 3

Het door controle en het toepassen (of dreigen daarme) van administratiefrechtelijke, strafrechtelijk of privaaterechtelijk middelen bereiken dat de algemeen en individueel geldende rechtsregels en vorschiften worden negeleefd.

(Pengawasan dan penerapan instrumen administratif, kepidanaan, atau keperdataan (bisa dengan ancaman) sehingga dicapai penaatan ketentuan hukum dan peraturan yang berlaku umum dan individual).

Dalam penegakan hukum preventif terkait dengan limbah B3, pengawasan aktif dilakukan terhadap kepatuhan peraturan tanpa kejadian langsung yang menyangkut peristiwa konkret yang menimbulkan sangkaan bahwa peraturan hukum telah dilanggar. ${ }^{4}$ Dari sini dapat dipahami bahwa penegakan hukum administrasi dimulai sejak begitu limbah B3 dihasilkan dari sisa hasil usaha atau kegiatan. Ketika suatu usaha atau kegiatan menghasilkan limbah B3, seketika itu diwajibkan untuk melakukan pengelolaan limbah B3 dengan mendasarkan pada ketentuan dan persyaratan yang berlaku. Ketentuan dan persyaratan yang berlaku seperti halnya kewajiban bagi setiap pelaku usaha atau kegiatan yang menghasilkan limbah B3 untuk melakukan pengelolaan limbah B3 di mana pengelolaan limbah B3 tersebut sebelumnya harus memperoleh ijin, adalah beberapa contoh ketentuan normatif yang diatur dalam ranah hukum administrasi.

Dalam UU PPLH, kewajiban untuk mengelola Limbah B3 dan kewajiban untuk memperoleh izin dalam pengelolaan limbah B3 diatur dalam Pasal 59 ayat (1) 5 dan Pasal 59 ayat (4) 6 UU PPLH yang merupakan ketentuan administrasi dalam pengelolaan limbah B3. Akan tetapi, berdasarkan UU PPLH, pelanggaran terhadap dua ketentuan tersebut diancam dengan sanksi pidana sebagaimana ditentukan

\footnotetext{
${ }^{3}$ Koesnadi Hardjosoemantri, Pengantar Penegakan Hukum Lingkungan Indonesia, makalah dalam Penataran Penegakan Hukum Lingkungan 9-14 Januari 1995, Eks Kerjasama Indonesia-Belanda, Surabaya: Fakultas Hukum Unair, hlm. 1, dalam Kartono, "Penegakan Hukum Administratif dalam Undang-Undang Perlindungan dan Pengelolaan Lingkungan Hidup”, Jurnal Dinamika Hukum, Volume 9 Nomor 3, September 2009, hlm. 249.

4 Siti Sundari Rangkuti, Hukum Lingkungan dan Kebijaksanaan Lingkungan Nasional, Airlangga University Press, Surabaya, 2010, hlm. 190.

${ }^{5}$ Setiap orang yang menghasilkan limbah B3 wajib melakukan pengelolaan limbah B3 yang dihasilkannya.

${ }^{6}$ Pengelolaan limbah B3 wajib mendapat izin dari Menteri, gubernur, atau bupati/walikota sesuai dengan kewenangannya.
} 
dalam Pasal 103 (bagi yang menghasilkan limbah B3 tetapi tidak melakukan pengelolaan) dan Pasal 102 (bagi yang melakukan pengelolaan limbah B3 tanpa izin).

Perubahan UU lingkungan hidup dari UU Nomor 23 Tahun 1997 (UU PLH) menjadi UU Nomor 32 Tahun 2009 memang menghendaki penguatan penegakan hukum pidana yang dalam UU PLH diterapkan secara ultimum remedium. Penegakan hukum pidana mengalami progesifitas dengan lahirnya UU PPLH yang menerapkan penegakan hukum pidana secara premium remedium. Namun demikian, penegakan hukum administratif tetap menjadi kor utama dalam perlindungan dan pengelolaan lingkungan hidup termasuk dalam pengelolaan sisa usaha atau kegiatan yang berupa limbah B3. Penegakan hukum administrasi menurut Mas Achmad Santosa merupakan kegiatan yang ditujukan untuk mencegah dan menanggulangi pencemaran dan/atau perusakan lingkungan hidup melalui pendayagunaan kewenangan administrasi sesuai dengan atribusi atau delegasi oleh undang-undang. ${ }^{7}$ Sarana hukum administrasi bersifat preventif yang bertujuan menegakkan peraturan perundang-undangan sebelum timbulnya kerugian materiil baik pada subyek hukum maupun pada lingkungan hidup. ${ }^{8}$

Instrumen administrasi lingkungan hidup erat kaitannya dengan pengawasan yang dilakukan oleh aparat pemerintah untuk mencegah terjadinya pencemaran lingkungan hidup akibat limbah B3. Hal demikian dipertegas dalam Pasal 77 UU PPLH yang melibatkan Menteri dalam penjatuhan sanksi administrasi apabila Pemerintah Daerah secara sengaja tidak menegakkan sanksi administrasi sebagai mana mestinya. Hal demikian oleh Bagir Manan disebut sebagai pengawasan negatif preventif, yaitu pengawasan yang dilakukan oleh organ pemerintahan yang lebih tinggi yang bertujuan untuk menghalangi terjadinya kelalaian organ pemerintah yang lebih rendah. ${ }^{9}$

Terlebih lagi, dalam menghadapi aktivitas pembangunan berkelanjutan (suistainable development) yang menjadi salah satu ruh dalam sistem pengelolaan

\footnotetext{
7 Mas Achmad Santosa, Good Governance \& Hukum Lingkungan, hlm. 248, dalam Syahrul Machmud, Penegakan Hukum Lingkungan Indonesia, Graha Ilmu, Yogyakarta, 2012, hlm. 178.

${ }^{8}$ Siti Sundari Rangkuti, Op. Cit., hlm. 192.

9 Bagir Manan, Hubungan antara Pusat dan Daerah Menurut UUD 1945, Pustaka Sinar Harapan, Jakarta, 1994, hlm. 107.
} 
lingkungan hidup, instrumen administrasi lingkungan hidup difungsikan untuk menjamin tetap terpeliharanya kelestarian kemampuan lingkungan hidup, sehingga generasi mendatang tetap memiliki sumber alam yang menunjang kesejahteraan dan kualitas kehidupannya. ${ }^{10}$ Dalam rangka menghadapi pembangunan berkelanjutan kaitannya dengan perlindungan lingkungan hidup, yang terpenting adalah mencegah terjadinya sengketa dan bukan menyelesaikan sengketa. Mencegah terjadinya sengketa adalah lebih baik daripada menyelesaikan sengketa yang terjadi. Hal tersebut sesuai prinsip bahwa "lebih baik mencegah daripada mengobati". ${ }^{11}$ Hukum administrasi merupakan tindakan pemerintah atau eksekutif atau bestuurmaatregel atau the measure/action of government terhadap pelanggaran perundang-undangan yang berlaku dan bersifat reparatoir (mengembalikan fungsi dan kondisi lingkungan pada keadaan semula). Berbeda halnya dengan sanksi hukum pidana yang bersifat condemnatoir (memberikan derita fisik maupun psikis) berupa penjara, denda, atau tindakan tata tertib lainnya. ${ }^{12}$

Selain itu penegakan hukum administrasi memiliki beberapa manfaat strategis jika dibandingkan dengan penegakan hukum perdata maupun pidana, yaitu: ${ }^{13}$ a. Penegakan hukum administrasi di bidang lingkungan hidup dapat dioptimalkan sebagai perangkat pencegahan; b. Penegakan hukum admnistrasi (yang bersifat pencegahan tersebut) dapat lebih efisien dari sudut pembiayaan dibandingkan penegakan hukum pidana dan penegakan hukum perdata. Pembiayaan untuk penegakan hukum administrasi meliputi biaya pengawasan lapangan yang dilakukan secara rutin dan pengujian laboratorium lebih murah jika dibandingkan dengan upaya pengumpulan bukti, investigas lapangan, memperkerjakan saksi ahli untuk membuktikan aspek kausalitas (sebab-akibat) dalam kasus pidana dan perdata; c. Penegakan hukum administrasi lebih memiliki kemampuan mengundang partisipasi msyarakat. Partisipasi masyarakat

${ }_{10}$ Moestadji, "Peran Hukum dalam Mewujudkan Konsep Pembangunan Berkelanjutan", Jurnal Hukum Lingkungan, Tahun I Nomor 1, Jakarta: ICEL, hlm. 26.

${ }^{11}$ Siti Sundari Rangkuti, Analisis UUPLH-199: Penataran Hukum Lingkungan dan Pembangunan Berkelanjutan, Eks Kerja Sama Hukum Indonesia-Belanda, Fakultas Hukum Universitas Airlangga, Surabaya, 9-14 Februari 1998, dalam A'an Efendi, Op. Cit., hlm. 108-109.

${ }^{12}$ Syahrul Machmud, Op. Cit., hlm. 179-182. hlm. 182.

${ }^{13}$ Mas Achmad Santosa, Good Governance \& Hukum Lingkungan, hlm. 248, dalam Syahrul Machmud, Ibid., 
dilakukan mulai dari proses perizinan, pemantauan penataan/pengawasan, dan partisipasi dalam mengajukan keberatan dan meminta pejabat tata usaha negara untuk memberlakukan sanksi administrasi.

Norma hukum administrasi yang memberikan beban atau kewajiban kepada masyarakat untuk mentaati aturan yang berkenaan dengan pengelolaan limbah B3 tentunya membutuhkan penegakan yang efektif oleh pejabat atau organ administrasi yang bersangkutan. Dengan kata lain, pemberian kewenangan kepada pemerintah untuk membuat peraturan perundang-undangan atau menetapkan norma hukum, secara implisist melekat pula kewenangan penegakkannya. Sanksi administrasi merupakan salah satu sarana atau cara penegakan hukum. ${ }^{14}$ Sedangkan penegakan hukum pidana terhadap tindakan yang melanggar ketentuan administrasi dalam pengelolaan limbah B3 yang diterapkan secara premium remedium bertujuan agar ketentuan administrasi terkait pengelolaan limbah B3 lebih memiliki kekuatan daya paksa serta mempertegas komitmen pemerintah Indonesia dalam mencegah terjadainya perusakan dan/atau pencemaran lingkungan yang disebabkan pengelolaan limbah B3 secara salah. Maka dari itu, instrumen sanksi administrasi mutlak diperlukan dalam pengelolaan limbah B3 terutama dalam melakukan upaya pencegahan.

Mengenai mana yang diterapkan terlebih dahulu antara sanksi administrasi dan sanksi pidana, H.G. de Bunt menjelaskan rambu-rambu dalam memilih penerapan instrumen administrasi atau instrumen pidana atau bahkan sekaligus keduanya, dapat dengan mempertimbangkan: (a). Kriteria normatif; (b). Kriteria instrumental; (c). Kriteria oportunis. ${ }^{15}$ Kriteria normatif berdasarkan pandangan bahwa instrumen pidana diterapkan terhadap pelanggaran yang mempunyai nilai etis negatif yang sangat tinggi (high ethical negative value). Selain itu, jika yang menjadi tujuan adalah pemulihan keadaan atau perbaikan kerusakan, namun aparat administrasi enggan bertindak atau bahkan terlibat dalam pelanggaran tersebut, maka instrumen pidana dapat mem-back up agar suatu pelanggaran dapat terselesaikan secara hukum. Hal yang sama diterapkan jika penerapan instrumen

${ }^{14}$ J.B.J.M. ten Berge, Besturen door de Overheid, Deventer, W.E.J. Tjeenk Willink, 1996, hlm. 372. 65.

${ }^{15}$ H.G. de Bunt, dalam Andi Hamzah, Penegakan Hukum Lingkungan, Sinar Grafika, Jakarta, 2005, hlm. 64- 
administrasi akan melalui prosedur yang sangat panjang, maka instrumen pidana dapat mem-back up agar perusakan dan/atau pencemaran lingkungan tidak berjalan berlarut-larut. Sebaliknya, jika pembuktian dalam hukum pidana sangat sulit, instrumen administrasi dapat mem-back up nya. ${ }^{16}$ Kriteria oportunis diterapkan jika sanksi administrasi tidak dapat ditegakkan, misalnya tidak dapat dilakukan paksaan administratif atau uang paksa (dwangsom) karena pelaku telah pailit atau bangkrut, maka instrumen hukum pidana yang akan mem-back up nya. Instrumen hukum pidana juga dapat mem-back up penarapan sanksi administrasi berupa pencabutan izin usaha, mengingat penjatuhan sanksi tersebut dapat menimbulkan dampak yang besar berupa timbulnya pengangguran karena pemutusan hubungan kerja dengan ditutupnya perusahaan. ${ }^{17}$ Sedangkan penjatuhan sanksi administrasi bersamaan dengan sanksi pidana atau penjatuhan sanksi secara komulasi eksternal tidak menyebabkan sebuah kasus menjadi nebis in idem. Menurut Fockema Andreae, asas nebis in idem diterapkan dalam mekanisme hukum pidana untuk kedua kalinya, bukan dalam penegakan bidang hukum yang berbeda (hukum administrasi dan hukum pidana). ${ }^{18}$

Maka dari itu, sanksi administrasi merupakan suatu keniscayaan dalam perlindungan dan pengelolaan lingkungan meskipun sanksi pidana diberakukan secara premium remedium, tidak terkecuali dalam pengelolaan limbah B3. Namun demikian, keberadaan sanksi administrasi dalam PP Nomor 101 Tahun 2014 tersebut belum sampai pada tahap mencegah potensi terjadinya pencemaran limbah B3 dan belum sampai pada tahap mengendalikan jumlah limbah B3 yang dihasilkan. Artinya, jumlah limbah B3 yang boleh dihasilkan dari tiap-tiap usaha atau kegiatan tidak ada batasnya sehingga beban pengawasan yang dilakukan pemerintah terkait ketaatan pelaku usaha atau kegiatan terhadap ketentuan PP Nomor 101 Tahun 2014 menjadi sangat berat.

Terlebih lagi jika melihat persoalan pencemaran lingkungan untuk jangka waktu ke depan, kita tidak bisa melihatnya hanya dengan menggunakan kaca mata saat ini. Artinya harus dilakukan pembaharuan perlindungan lingkungan hidup

\footnotetext{
${ }^{16} \mathrm{Ibid}$.

${ }^{17}$ Ibid.

${ }^{18}$ Ibid., hlm. 72-73.
} 
dengan mengutamakan langkah pencegahan, khususnya pada persoalan limbah B3. Dunia internasional telah mengadopsi asas pencegahan dan negara-negara maju telah menerapkan asas pencegahan pencemaran melalui berbagai instrumen, termasuk salah satunya adalah instrumen ekonomi. ${ }^{19}$ Lahirnya konsep pencegahan pencemaran sebagai asas dalam pengelolaan limbah B3 dilatarbelakangi oleh munculnya kesadaran, bahwa pengendalian pencemaran berdasarkan pendekatan "end-of-pipe" yang selama ini diterapkan di banyak negara ternyata tidak efektif. Hal tersebut dapat diketahui dari adanya kelemahan pengendalian pencemaran lingkungan berdasarkan end-of-approaches, titik tekannya hanya pada upaya pengolahan limbah B3 dan bukan pada upaya peniadaan, pengurangan atau pencegahan adanya limbah. ${ }^{20}$

Kelemahan lain dari konsep pengendalian pencemaran adalah terletak pada ketidakmampuan untuk mengatasi secara terpadu pencemaran lingkungan yang dapat terjadi pada tiga tahapan, yaitu tahap proses manufaktur di pabrik-pabrik, tahap penggunaan produk, dan tahap setelah produk selesai dikonsumsi atau dimanfaatkan yang menghasilkan limbah. Upaya pengendalian pencemaran pada tahap proses manufaktur tidak dapat diterapkan pada masalah pencemaran tahap kedua dan ketiga. Ketidakpuasan terhadap konsep pengendalian pencemaran melahirkan pemikiran-pemikiran untuk menemukan pemecahan masalah pencemaran lingkungan pada akar masalahnya, yaitu melalui penyerapan dan pemberlakuan konsep pencegahan pencemaran (pollution prevention). ${ }^{21}$

Amerika Serikat merupakan negara yang secara formal menuangkan konsep pencegahan pencemaran ke dalam sebuah undang-undang yang dikenal dengan Pollution Prevention Act yang menetapkan kebijakan lingkungan akibat B3 berdasarkan pada prioritas-prioritas. Pertama, pencemaran sedapat mungkin dicegah atau direduksi pada sumbernya. Kedua, jika limbah tetap dihasilkan atau tidak dapat dicegah kehadirannya, maka limbah sedapat mungkin didaur ulang dengan cara yang berwawasan lingkungan. Ketiga, limbah yang tidak dapat

${ }^{19}$ Instrumen ekonomi ingkungan hidup sebenarnya telah diamanatkan oleh UU Nomor 32 Tahun 2009 melalui pengeturan lebih lanjut dalam Peraturan Pemerintah tentang Instrumen Ekonomi Lingkungan Hidup. Akan tetapi, pengaturan tersebut sampai saat ini masih dalam bentuk Rancangan Peraturan Pemerintah (RPP).

${ }^{20}$ Takdir Rahmadi, Hukum Pengelolaan Bahan Berbahaya dan Beracun, Airlangga University Press, Surabaya, 2003, hlm. 216-217.

${ }^{21}$ Ibid., hlm. 217. 
dicegah kehadirannya atau tidak dapat didaur ulang, harus diolah secara berwawasan lingkungan. Keempat, pembuangan (disposal) atau cara pelepasan lain ke dalam media lingkungan harus menjadi pilihan terakhir dan dilakukan secara berwawasan lingkungan. ${ }^{22}$

Langkah-langkah progresif dalam perlindungan lingkungan dengan menitikberatkan pada langkah pencegahan di atas sangat mensyaratkan peran pemerintah untuk aktif tidak hanya pada penegakan hukum administrasi tetapi lebih jauh dari itu juga menerapkan mekanisme insentif bagi pelaku usaha atau kegiatan untuk menekan produksi limbah B3 yang sangat potensial mencemari lingkungan.

\section{Efektivitas Sanksi Administrasi dalam Pengelolaan Limbah B3}

Keberdaan PP Nomor 101 Tahun 2014 merupakan pelimpahan atau pendelegasian dari Pasal 59 ayat (7) UU PPLH di mana pasal lainnya yaitu Pasal 76 memberikan kewenangan kepada pemerintah untuk menjatuhkan sanksi administrasi terhadap pelanggar ketentuan administrasi dalam bidang pengelolaan limbah B3. Pemberlakuan sanksi administrasi dan sanksi pidana terhadap perkara yang sama menyebabkan suatu pelanggaran administrasi menjadi 'over sanksi'. Terlebih lagi delik pidana yang diancamkan atas pelanggaran administrasi dalam Pasal 102 dan Pasal 103 merupakan jenis delik pidana formal. Delik formal itu sendiri adalah jenis perbuatan pidana yang tergantung pada hukum administrasi atau diistilahkan Administrative Dependent Crime (ADC). Pada delik formal (ADC) tidak atau belum dipersyaratkan pembuktian apakah lingkungan telah tercemar atau telah rusak. Akan tetapi cukup dibuktikan apakah tersangka atau terdakwa telah melanggar ketentuan perundang-undangan tentang persyaratan izin yang merupakan ranah dari hukum administrasi. Dalam kaitannya dengan hal ini, Pasal 103 dan Pasal 102 UU PPLH merupakan norma delik pidana formal, yang apabila pelaku usaha atau kegiatan tidak mengelola limbah B3 nya atau mengelola limbah B3 tanpa ijin, maka penegakan hukum pidana terhadapnya dapat serta merta dilakukan bersamaan dengan diberlakukannya sanksi administrasi. 
Pada tataran implementasi, sering kali sanksi administrasi lebih ampuh menyelesaikan suatu tindakan pelanggaran ketentuan administrasi yang oleh UUPPLH diancam dengan sanksi pidana melalui perumusan delik pidana formal, tidak terkecuali dalam bidang pengelolaan limbah B3, khususnya yang terkait dengan ketentuan Pasal 59 ayat (1) dan Pasal 59 ayat (4) UUPPLH. Sanksi pidana memang dapat menjerakan pencemar yang merusak lingkungan dengan sanksi pidana penjara, kurungan, atau denda. Namun, sanksi pidana sebenarnya mempunyai batas-batas kemampuan, diantaranya: (1). apabila dilihat dari sifat dan fungsi pemidanaan selama ini, yaitu pemidanaan individual atau personal dan bukan pemidanaan yang bersifat struktural atau fungsional. Pemidanaan yang bersifat individual atau personal kurang menyentuh pada sisi lain yang berhubungan erat secara struktural atau fungsional dengan perbuatan (dan akibat perbuatan) dari si pelaku; (2). Sanksi pidana sangat kaku dan terbatasnya jenis pidana (sebagai obat/remedium) yang dapat dipilih untuk memidana terdakwa. Tidak sedikit dalam perundang-undangan selama ini digunakan sistem perumusan sanksi pidana yang sangat kaku dan bersifat imperatif seperti perumusan sanksi pidana secara tunggal dan komulatif. ${ }^{23}$

Pendapat lain juga menjelaskan bahwa penerapan sanksi administrasi mempunyai beberapa kelebihan jika dibandingkan dengan jenis sanksi lain, baik sanksi pidana maupun perdata. Sanksi pidana ditujukan pada pelanggar agar menimbulkan rasa jera atau nestapa. Sanksi perdata yakni pembayaran ganti kerugian ditujukan kepada korban atas kerugian yang diderita akibat perbuatan melanggar hukum. Ganti kerugian kepada korban tidak dapat memulihkan lingkungan hidup yang telah tercemar. Berbeda dengan tujuan kedua sanksi tersebut, sanksi administrasi ditujukan kepada pencegahan dan penghentian pelanggaran dan sekaligus juga upaya pemulihan lingkungan hidup yang rusak atau tercemar akibat perbuatan pelaku. ${ }^{24}$

${ }^{23}$ Barda Nawawi Arief, Bunga Rampai Kebijakan Hukum Pidana, Bandung, Citra Aditya Bakti, 1996, hlm. 4546, dikutip kembali oleh Teguh Sulistina \& Aria Zurnetti, Hukum Pidana: Horizon Baru Pasca Reformasi, Jakarta, Rajawali Pers, 2011, hlm. 172.

${ }^{24}$ Harry Agung Ariefianto, Penerapan Sanksi Administrasi Pencemaran Lingkungan Hidup Akibat Kegiatan Industri, Unnes Law Journal, Vol. 4 No. 1, 2015, hlm. 87. 
Dari dua pandangan di atas, sanksi administrasi dalam perlindungan dan pengelolaan lingkungan hidup menitikberatkan pada upaya perlindungan lingkungan hidup dan upaya penanggulangan lingkungan hidup apabila pencemaran telah terjadi. Fokus dari sanksi administrasi adalah pada terjaganya lingkungan hidup dari pencemaran maupun perusakan lingkungan. Sedangkan instrumen sanksi pidana dan perdata lebih menitikberatkan pada subyek hukum yang melakukan pencemaran dan subyek hukum yang mengalami kerugian akibat pencemaran, sedangkan kondisi lingkungan yang telah tercemar tidak menjadi fokus utama dalam penegakan sanksi pidana dan sanksi perdata. Sehingga bagi kelestarian lingkungan, sanksi administrasi lebih ampuh dan diandalkan.

Hal demikian juga ditegaskan oleh Mas Achmad Santosa yang menyebutkan kelemahan dari penegakan hukum pidana lingkungan secara umum sebagai berikut:25 1. Proses pengumpulan bahan keterangan (pra-penyidikan), penyidikan, dan penuntutan dilakukan oleh instansi yang berbeda-beda dengan kemampuan koordinasi yang sangat lemah. Keterangan biasanya dikumpulkan oleh Bapedal, penyidikan oleh polisi, penuntutan oleh jaksa, di mana polisi dan jaksa bukan khusus menangani kasus lingkungan. Koordinasi diantara keduanya sangat memakan waktu, terlebih lagi jika presepsi yang dimiliki masing-masing berbeda; 2. Tidak dikenalnya lembaga expert judge (hakim ad hoc) yaitu seorang ahli lingkungan yang berperan sebagai anggota majelis hakim untuk megatasi keawaman hakim di bidang hukum lingkungan; 3. Belum adanya pedoman penegakan hukum dan pentaan lingkungan yang dapat dijadikan acuan bagi aparat penegak hukum; 4. Akses masyarakat terhadap informasi status penataan suatu kegiatan masih tertutup, jika pun ada aksesnya masih sangat terbatas. Jaminan ini dapat menjadikan peran masyarakat dan organisasi lingkungan sebagai pengawas eksternal yang efektif dari proses penegakan hukum pidana lingkungan; 5. Integritas lembaga peradilan.

Maka dari itu, pada tataran implementatif, sanksi pidana dalam delik pidana formal, khususnya dalam bidang pengelolaan limbah B3 dipandang kurang aplikatif jika dibandingkan dengan sanksi administrasi sehingga re-desain sanksi

${ }^{25}$ Mas Achmad Santosa dalam Syahrul Machmud, Op. Cit., hlm. 264. 
pidana yang diberlakukan secara premium remedium perlu dikaji kembali. Akan lebih tepat dan efektif jika sanksi administrasi diberlakukan terlebih dahulu jika pelaku usaha atau kegiatan melanggar norma perijinan sebagaimana yang diatur dalam Pasal 59 ayat (1) dan Pasal 59 ayat (2) UU PPLH, sedangkan sanksi pidana diberlakukan pada tataran delik materiil yang artinya sanksi pidana dijatuhkan apabila tindakan yang melanggar norma administrasi menimbulkan korban jiwa atau sanksi administrasi tidak efektif dalam menertibkan suatu kegiatan usaha. Selain itu, jika titik tekannya adalah pada pemulihan fungsi lingkungan hidup, akan lebih tepat dan efektif jika sanksi administrasi dikedepankan dari pada sanksi pidana sebab fokus utama dari sanksi pidana adalah pada pelaku atau subyek yang melakukan tindakan yang melanggar ketentuan norma administrasi, bukan pada pemulihan fungsi lingkungan hidup. Hal lain juga yang tidak kalah penting adalah terkait dengan aparat yang berwenang dalam menegakkan sanksi. Sanksi administrasi dipandang lebih efektif dalam menindak pelaku usaha atau kegiatan yang melanggar ketentuan administrasi dalam pengelolaan limbah B3 karena sanksi administrasi ditegakkan oleh organ pemerintah yang diberi kewenangan khusus untuk itu seperti Badan Lingkungan Hidup Kabupaten/Kota/Provinsi atau Menteri yang membidangi lingkungan hidup, sedangkan sanksi pidana ditegakkan oleh kepolisian yang kita tahu perkara yang ditanganinya sangat beragam, tidak dikhususkan dalam bidang perlindungan lingkungan dan berbagai macam kendala lainnya.

\section{Penutup}

Berdasarkan kajian di atas, dapat disimpulkan bahwa keberadaan sanksi administrasi dalam pengaturan pengelolaan limbah B3 sangatlah urgen sifatnya mengingat sanksi administrasi merupakan instrumen hukum yang paling efektif bagi pemerintah untuk melakukan tindakan pencegahan. Namun demikian, pencegahan pencemaran dan perusakan lingkungan akibat limbah B3 melalui instrumen administrasi hendaknya tidak hanya sebatas pada pelanggaran ketentuan-ketentuan administrasi semata, melainkan juga perlu dikembangkan mekanisme pencegahan yang sifatnya memberdayakan masyarakat luas (encouragement), terutamanya di kalangan masyarakat industri. 
Pada tataran implementasi, pelanggaran terhadap Pasal 59 ayat (1) dan Pasal 59 ayat (2) UU PPLH akan lebih tepat dan efektif jika sanksi administrasi lebih dikedepankan dari pada sanksi pidana karena ketentuan pidana yang diatur oleh UU PPLH terhadap pelanggar Pasal 59 ayat (1) dan Pasal 59 ayat (2) sebagaimana ditentukan dalam Pasal 102 dan Pasal 103 UU PPLH merupakan jenis delik pidana formal. Sehingga dalam satu pelanggaran terhadap ketentuan administrasi dapat dijatuhi dua jenis sanksi, sanksi administrasi dan sanksi pidana. Hal demikian menyebabkan terjadinya 'over sanksi' terhadap pelanggaran Pasal 59 ayat (1) dan Pasal 59 ayat (2) UU PPLH. Sanksi administrasi dipandang lebih efektif juga karena beberapa kendala penerapan sanksi pidana dengan delik formal, seperti tidak terfokusnya kerja aparat kepolisian di bidang perlindungan lingkungan hidup, proses penegakan hukum pidana yang memakan waktu yang relatif lebih lama dibandingkan penegakan hukum administrasi, perbedaan pemahaman antara kepolisian dan kejaksaan dalam persoalan lingkungan hidup, ketiadaan hakim ad hoc dengan keahlian di bidang lingkungan hidup, dan juga independensi lembaga peradilan itu sendiri. Sedangkan penegakan hukum administrasi dilakukan oleh organ pemeritah yang kewenangannya khusus dalam bidang lingkungan hidup dan juga kewenangan pengawasan yang dimiliki pemerintah menyebabkan pelanggaran terhadap norma administrasi lebih cepat terdeteksi oleh aparat pemerintah dari pada aparat kepolisian.

Dengan demikian, perlu kiranya mendesain ulang konsep sanksi pidana sebagai premium remedium yang dirumuskan dalam bentuk delik pidana formal, khususnya dalam pengelolaan limbah B3 dan agar lebih dikedepankan penegakan hukum administrasi jika pelanggaran norma administrasi Pasal 59 ayat (1) dan Pasal 59 ayat (4) UU PPLH tidak sampai menimbulkan korban jiwa.

\section{Daftar Pustaka}

\section{Buku}

Arief, Barda Nawawi, Bunga Rampai Kebijakan Hukum Pidana, Citra Aditya Bakti, Bandung, 1996.

Hamzah, Andi, Penegakan Hukum Lingkungan, Sinar Grafika, Jakarta, 2005.

Machmud, Syahrul, Penegakan Hukum Lingkungan Indonesia, Graha Ilmu, Yogyakarta, 2012. 
Manan, Bagir, Hubungan antara Pusat dan Daerah Menurut UUD 1945, Jakarta, Pustaka Sinar Harapan, 1994.

Rahmadi, Takdir, Hukum Pengelolaan Bahan Berbahaya dan Beracun, Airlangga University Press, Surabaya, 2003.

Rangkuti, Siti Sundari, Hukum Lingkungan dan Kebijaksanaan Lingkungan Nasional, Airlangga University Press, Surabaya.

Sulistina, Teguh \& Aria Zurnetti, Hukum Pidana, Horizon Baru Pasca Reformasi, Rajawali Pers, Jakarta, 2011.

Supriadi, Hukum Lingkungan Indonesia: Sebuah Pengantar, Sinar Grafika, Jakarta, 2006.

\section{Artikel Jurnal}

Ariefianto, Harry Agung, Penerapan Sanksi Administrasi Pencemaran Lingkungan Hidup Akibat Kegiatan Industri, Unnes Law Journal, Vol. 4 No. 1, 2015.

Kartono. "Penegakan Hukum Administratif dalam Undang-Undang Perlindungan dan Pengelolaan Lingkungan Hidup", Jurnal Dinamika Hukum, Volume 9 Nomor 3, September 2009.

Moestadji. "Peran Hukum dalam Mewujudkan Konsep Pembangunan Berkelanjutan", Jurnal Hukum Lingkungan, Tahun I Nomor 1, Jakarta, ICEL.

Widyawati, Lidya Suryani. "Ultimum Remedium dalam Bidang Lingkungan Hidup", Jurnal Hukum Ius Quia Istum, Volume 22, Nomor 1, Januari 2015.

Peraturan Perundang-Undangan Undang-Undang Nomor 32 Tahun 2009 tentang Perlindungan dan Pengelolaan Lingkungan Hidup (Lembaran Negara Republik Indonesia Tahun 2009 Nomor 140).

Peraturan Pemerintah Nomor 101 Tahun 2014 tentang Pengelolaan Limbah Bahan Berbahaya dan Beracun (Lembaran Negara Republik Indonesia Tahun 2014 Tahun 333). 